\title{
Combined Diet and Supplementation Therapy Resolves Alopecia Areata in a Paediatric Patient: A Case Study
}

Cliff J. Harvey ${ }^{1}$

1. Clinical Nutrition, The Holistic Performance Institute, Auckland, NZL

Corresponding author: Cliff J. Harvey, cliff.harvey@gmail.com

\begin{abstract}
Alopecia areata (AA) is a common autoimmune condition resulting in spot baldness and, rarely, more extensive hair loss. There is an association between both the incidence and the severity of AA and several micronutrients, including vitamin D and zinc. This case reports an eight-year-old male diagnosed with AA and treated with a diet and supplemental regimen based on unrefined foods, rich in vitamins A and D, zinc, and supplemented with a multi-nutrient, zinc sulfate, and fish oil with vitamin D. Complete remission of AA was achieved within five months.
\end{abstract}

Categories: Pediatrics, Allergy/Immunology, Other

Keywords: alopecia areata, nutrition, vitamin d, zinc, vitamin a, supplementation

\section{Introduction}

Alopecia areata (AA), sometimes known as 'spot baldness' is a condition in which hair is lost, typically in patches over some of the body but occasionally becoming more severe and affecting the entire body. The condition affects around $2 \%$ of people at some time in their life [1]. It is believed to be an autoimmune disease with some inheritability, and different immune-cell lines, including plasmacytoid dendritic cells, natural killer cells, and T cells, along with key molecules, such as interferon- $\gamma$, interleukin-15, MICA and NKG2D, and CD8 T cells have been identified as contributing to the autoimmune process [2-3]. Genomewide association studies provide evidence for the involvement of both innate and acquired immunity in the pathogenesis of AA [3]. There is also evidence that AA is associated with oxidative stress [4].

\section{Case Presentation}

An eight-year-old male presented for nutritional and supplemental advice secondary to a diagnosis of alopecia areata. Initial blood tests were within normal ranges for C-reactive protein, fasting glucose, ferritin, liver enzymes, electrolytes, and all complete blood count measures. Coeliac disease was ruled out due to tissue transglutan immunoglobulin A (IgA) $<0.5 \mathrm{U} / \mathrm{ml}$ and total IgA $0.4 \mathrm{~g} / \mathrm{L}$. Thyroid disease was not

Review began 09/30/2020 Review ended 10/28/2020 Published 11/07/2020

\section{(c) Copyright 2020} Harvey. This is an open access article distributed under the terms of the Creative Commons Attribution License CC-BY 4.0., which permits unrestricted use, distribution, and reproduction in any medium, provided the original author and source are credited. suspected, as thyroid peroxidase antibodies were within normal ranges $(37 \mathrm{U} / \mathrm{ml})$ and thyroid-stimulating hormone was $2.6 \mathrm{mIU} / \mathrm{L}$.

Further blood tests were requested for vitamin B12 and folate, magnesium, serum zinc, rheumatoid factors, anti-nuclear antibodies, along with a repeat complete blood count. Except for marginally low neutrophils and monocytes, no abnormalities were noted. Serum zinc returned a 'normal' range result of $0.68 \mathrm{mcg} / \mathrm{ml}$ but this was below the suggested lower threshold of $>0.7 \mathrm{mcg} / \mathrm{ml}$ for functional outcomes in boys of this age (6-9 yrs.) [5]. Similarly, while the 25 hydroxyvitamin D (25(OH)D) result of $90 \mathrm{nmol} / \mathrm{L}$ was within reference ranges, it has been suggested that the lower threshold for optimum $25(\mathrm{OH}) \mathrm{D}$ status is $>100 \mathrm{nmol} / \mathrm{L}[6]$.

\section{Clinical course}

The patient's parents were provided with advice to increase zinc and vitamin A and D-rich foods, avoid gluten and dairy where able, and to focus on a diet that prioritizes foods in their natural forms in preference to highly processed 'packaged' foods. Also, a supplementation regimen consisting of a multi-nutrient (multi) powder rich in vitamins A and D3, zinc, and secondary antioxidant nutrients (Kids Good Stuff, Nuzest, Potts Point NSW, Australia), a zinc sulfate supplement (zinc drops, Clinicians Ltd., Australia), and fish oil with added vitamin D (fish oil + vitamin D, Melrose, Victoria, Australia) was provided (key nutrient summary in Table 1), along with lifestyle advice to get outside for 5-10 min per day without sunblock on. A full list of the multi-nutrient ingredients can be found in Appendix 1. 


\section{Cureus}

\begin{tabular}{|c|c|c|}
\hline & Amount provided in the supplements & Total supplemental dose per day \\
\hline Vitamin A ( $\mu \mathrm{g}$ RE) & Multi: 400 & 400 \\
\hline Vitamin D3 $(\mu \mathrm{g})$ & Multi: 10, Fish oil: 12.5 & 22.5 (900 iu) \\
\hline Zinc (mg) & Multi: 6, Zinc drops: 4 & 10 \\
\hline Omega 3 fatty acids (mg) & Fish oil: DHA - 273, EPA - 410 & 683 (total n-3 fatty acids) \\
\hline
\end{tabular}

\section{TABLE 1: Amounts of supplemental nutrients provided}

RE: retinol equivalent; DHA: docosahexaenoic, EPA: eicosapentaenoic acid

A sample of the dietary advice is provided below.

Vitamin A: Fish oil, liver, oily fish (herring, sardines, salmon, cod), eggs, chicken Also: kumara, pumpkin, carrots, mangos, apricots, broccoli, full-fat yogurt and milk*

Vitamin D: Cod liver oil, liver, fatty fish, full-fat milk and yogurt*

Note: It is imperative to use full-fat foods, as vitamins A and D are fat-soluble.

Zinc: Oysters, beef, pork, chicken, pumpkin seeds, full-fat yogurt*, almonds, fish

Note: Excessive intake of cereal grains might inhibit some zinc absorption.

*We are reducing/avoiding dairy in this phase, but these foods can be reintroduced to test tolerance when symptoms abate.

On presentation, the client had experienced severe hair loss with the involvement of the eyelashes, eyebrows, and mostly spot baldness on the crown of the head (Figure 1). 


\section{Cureus}

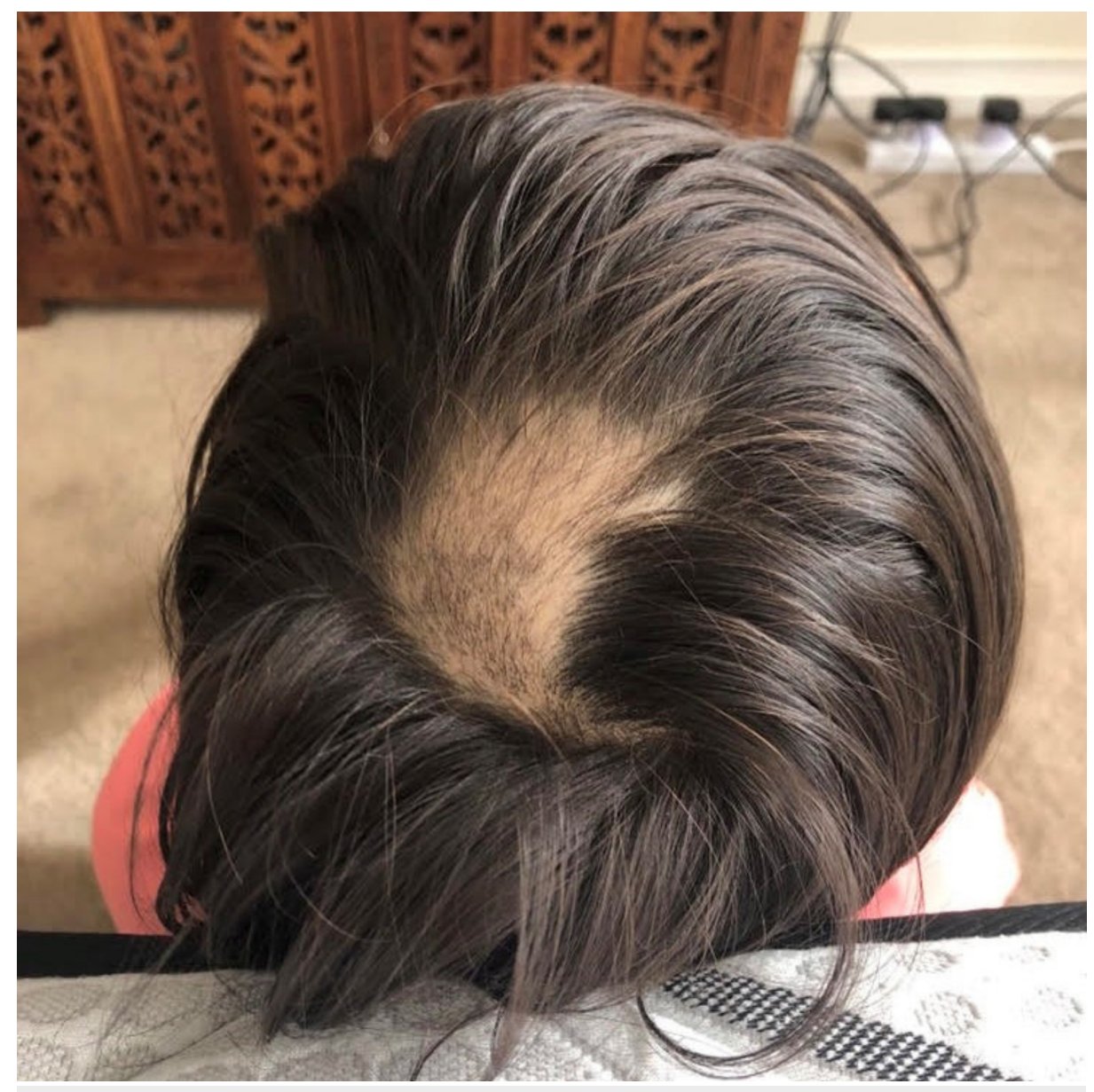

FIGURE 1: Spot baldness one week after the initial consultation

After following the prescribed dietary regimen for two months, the patient's hair can be seen to be regrowing in Figure 2. 


\section{Cureus}

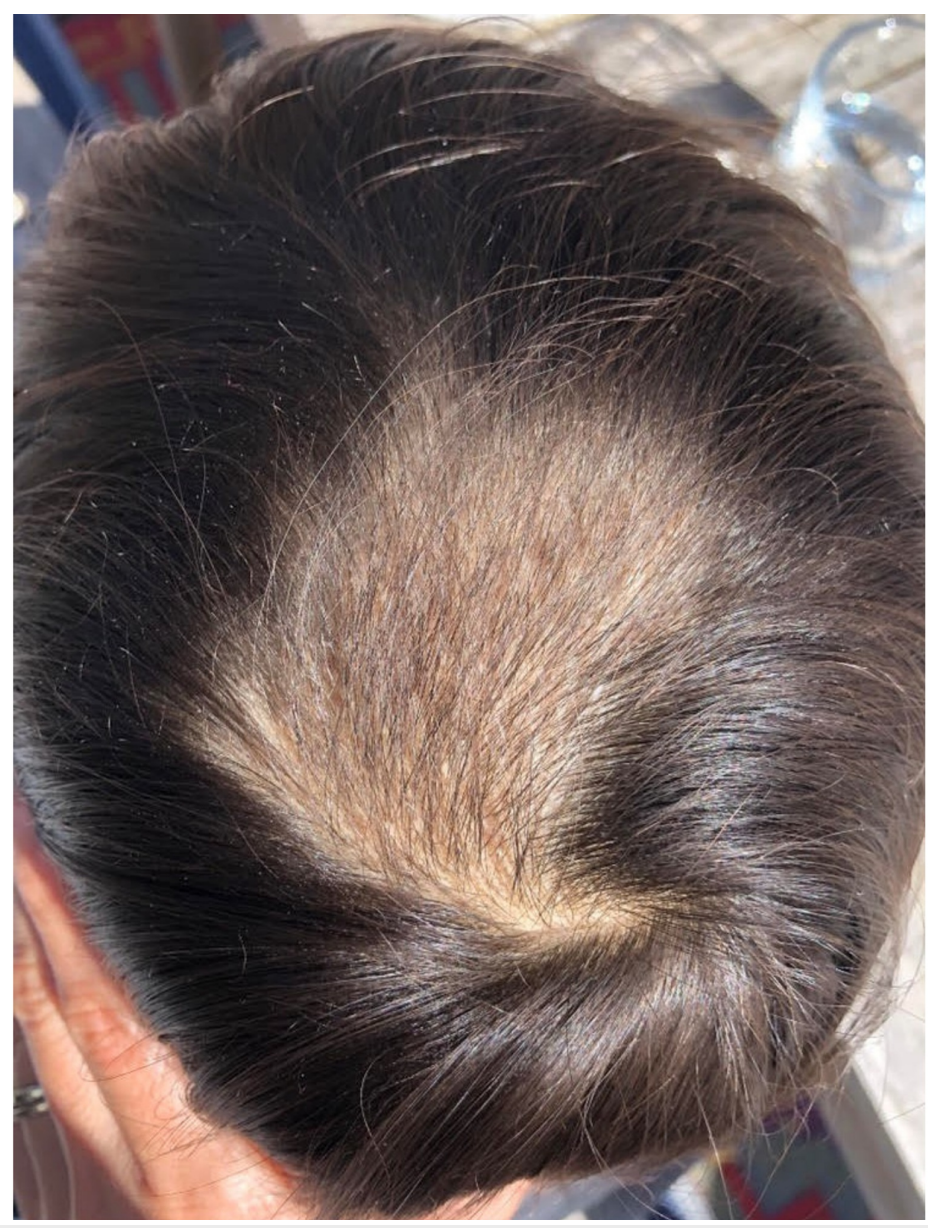

FIGURE 2: Patient hair regrowth at two months

Five months following commencement of the diet and supplement regimen, the hair on the crown was completely recovered and the patient's mother reported that the eyelashes and eyebrows were growing back (Figure 3). Approximately two weeks after commencing the diet and supplementation regimen, the patient exhibited a limited, minor popular rash on the cheeks, which resolved shortly afterwards and by August, there were no signs of any eczema-like skin conditions. 


\section{Cureus}

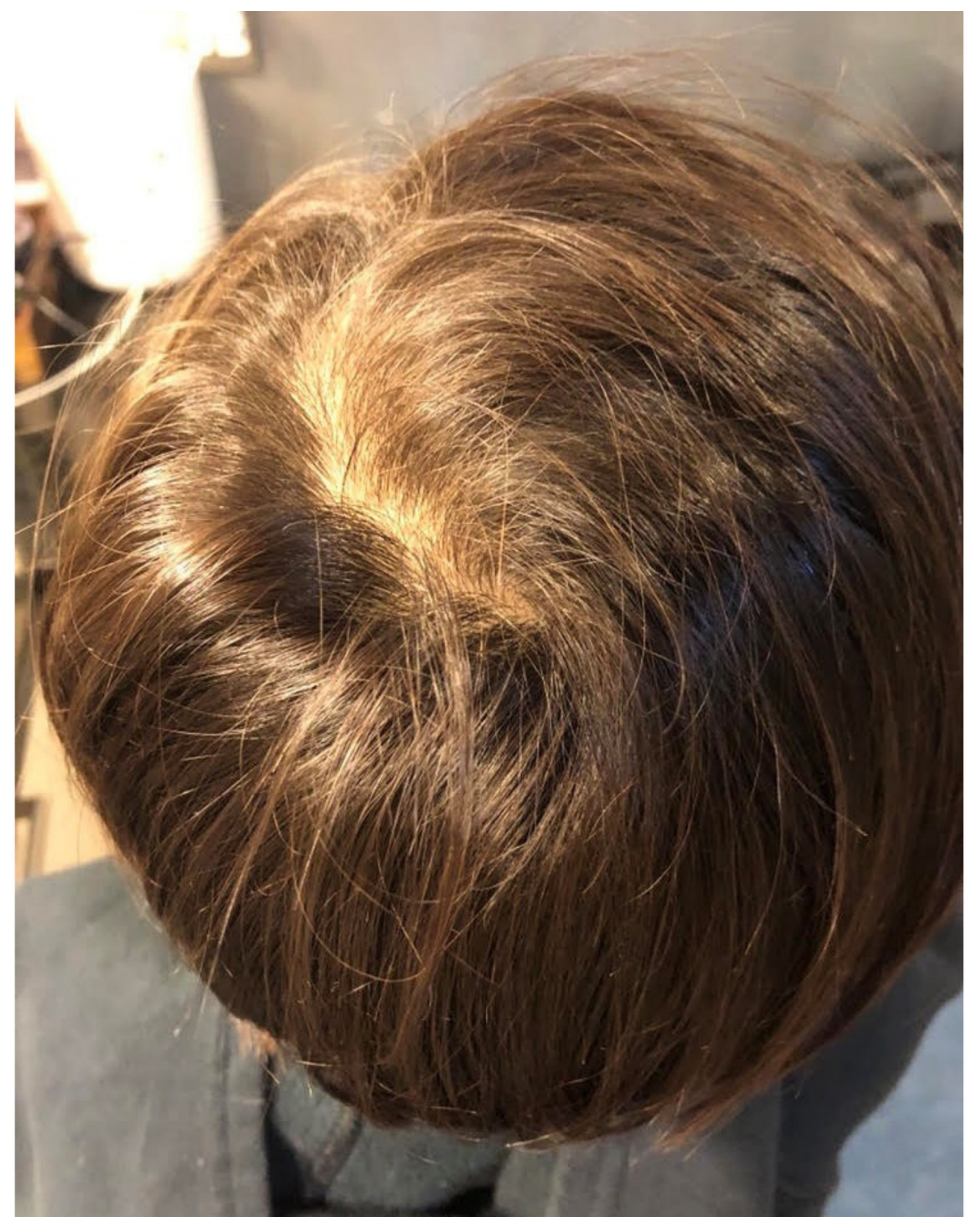

FIGURE 3: Patient hair regrowth five months following commencement of the diet and supplement regimen

\section{Discussion}

Patients with AA tend to have lower serum vitamin D, zinc, and folate levels as compared to controls, and evidence also suggests that vitamin A status may help modify the disease [7].

In particular, vitamin D status appears to be markedly different in patients with AA. Vitamin D levels (serum 25(OH)D) in patients with alopecia have been demonstrated to be significantly lower than in healthy controls (11.84 $\pm 6.18 \mathrm{vs} 23.57 \pm 9.03 \mathrm{ng} / \mathrm{mL} \mathrm{p} \mathrm{<} \mathrm{0.001)} \mathrm{[8],} \mathrm{and} \mathrm{the} \mathrm{prevalence} \mathrm{of} \mathrm{vitamin} \mathrm{D} \mathrm{deficiency}$ significantly higher [9]. Disease severity in AA also appears to be inversely correlated to vitamin D status [8,10-11]. While there have not been significant genetic differences (gene polymorphisms) shown for the vitamin D receptor (expressed in hair follicles) between alopecia and controls [12], tissue vitamin D receptor levels in tissue are lower in alopecia versus controls [13] and this is associated with increased inflammation but not vitamin D levels or severity and pattern of illness [14].

Serum zinc levels have also been demonstrated to be lower in people with AA as compared to health controls $(t=4.206, p=0.001)$ and are associated with the severity of the condition $(r=-0.573, p=0.001)[15]$. Other research has also demonstrated that alopecia patients have significantly lower zinc levels than controls [1617]. For example, Orecchia and colleagues observed a mean plasma zinc level of 74.2 versus $95.5 \mu \mathrm{g} / 100 \mathrm{ml}$ in cases as compared to controls respectively [17]. And while some studies have shown no significant difference in serum zinc levels between alopecia patients and controls, subgroup analysis revealed lower zinc levels in those with greater disease severity [18].

While this case has focussed on key nutrients with demonstrable associations with either disease incidence or severity, others such as biotin [19] have also been implicated and warrant further research.

Therefore, it is likely that nutrient-repletion is a critical and yet often overlooked strategy in the treatment of AA. 


\section{Cureus}

\section{Conclusions}

Vitamin D and zinc (and vitamin A) are critical to immune function and may provide an adjunct treatment option for AA. Insufficiency of these key micronutrients, whether primary or secondary to genetic polymorphisms, is linked to both the incidence and severity of AA. Normal cycles of relapse and remission common to autoimmune conditions, the placebo effect, or lifestyle factors may have contributed to or been responsible for the remission seen in this case and ongoing observation and follow-up will help to ascertain this. However, it demonstrates that a diet, excluding common autoimmune trigger foods and replete in key micronutrients, holds promise for the treatment of this condition, and research is warranted to investigate this hypothesis further.

\section{Appendices}

\begin{tabular}{|c|c|c|}
\hline & Amount provided in the multi-nutrient & \% RDI \\
\hline Vitamin A & $400 \mu \mathrm{g}$ RE & 63 \\
\hline Thiamin (B1) & $2.2 \mathrm{mg}$ & 244 \\
\hline Riboflavin (B2) & $3.4 \mathrm{mg}$ & 354 \\
\hline Vitamin B3 & $10 \mathrm{mg}$ & 81 \\
\hline Pantothenic acid & $5 \mathrm{mg}$ & 109 \\
\hline Vitamin B6 & $1.6 \mathrm{mg}$ & 160 \\
\hline Folate & $200 \mu \mathrm{g}$ & 67 \\
\hline Vitamin B12 & $5 \mu \mathrm{g}$ & 278 \\
\hline Vitamin C & $100 \mathrm{mg}$ & 261 \\
\hline Vitamin D3 & $10 \mu \mathrm{g}$ & 200 \\
\hline Vitamin E & 10 mg TE & 122 \\
\hline Vitamin $\mathrm{K}$ & $80 \mu \mathrm{g}$ & 178 \\
\hline Biotin & $60 \mu \mathrm{g}$ & 280 \\
\hline Calcium & $206 \mathrm{mg}$ & 21 \\
\hline Magnesium & $50 \mathrm{mg}$ & 18 \\
\hline Zinc & $6 \mathrm{mg}$ & 83 \\
\hline Iron & $1.4 \mathrm{mg}$ & 13 \\
\hline Manganese & $1 \mathrm{mg}$ & 34 \\
\hline Copper & $0.3 \mathrm{mg}$ & 25 \\
\hline Selenium & $21 \mu \mathrm{g}$ & 40 \\
\hline Chromium & $20 \mu \mathrm{g}$ & 83 \\
\hline lodine & $75 \mu \mathrm{g}$ & 63 \\
\hline
\end{tabular}

\section{TABLE 2: Nutritional information of Nuzest Kids Good Stuff}

RE: retinol equivalent; TE: tocopherol equivalent

Percent of average recommended daily intake for children ages 4-14

\section{Additional Information \\ Disclosures}

Human subjects: Consent was obtained by all participants in this study. Conflicts of interest: In compliance with the ICMJE uniform disclosure form, all authors declare the following: Payment/services info: All authors have declared that no financial support was received from any organization for the 
submitted work. Financial relationships: Cliff Harvey declare(s) personal fees from Melrose Health. Cliff Harvey has provided consultancy services to Melrose Health. . Cliff Harvey declare(s) personal fees and stock/stock options from Nuzest. Cliff Harvey is a stakeholder in Nuzest and has received consultancy fees and stock options. . Other relationships: All authors have declared that there are no other relationships or activities that could appear to have influenced the submitted work.

\section{References}

1. Lee HH, Gwillim E, Patel KR, Hua T, Rastogi S, Ibler E, Silverberg JI: Epidemiology of alopecia areata, ophiasis, totalis, and universalis: A systematic review and meta-analysis. J Am Acad Dermatol. 2020, 82:675682.

2. Rajabi F, Drake LA, Senna MM, Rezaei N: Alopecia areata: a review of disease pathogenesis . Br J Dermatol. 2018, 179:1033-1048. 10.1111/bjd.16808

3. Trüeb RM, Dias MFRG: Alopecia areata: a comprehensive review of pathogenesis and management . Clin Rev Allergy Immunol. 2018, 54:68-87. 10.1007/s12016-017-8620-9

4. Acharya P, Mathur MC: Oxidative stress in alopecia areata: a systematic review and meta-analysis . Int J Dermatol. 2020, 59:434-440. 10.1111/ijd.14753

5. Alves CX, de Brito NJN, Vermeulen KM, et al.: Serum zinc reference intervals and its relationship with dietary, functional, and biochemical indicators in 6- to 9-year-old healthy children. Food Nutr Res. 2016, 60:30157-30157. 10.3402/fnr.v60.30157

6. Vieth R: What is the optimal vitamin D status for health? . Prog Biophys Mol Biol. 2006, 92:26-32.

7. Thompson JM, Mirza MA, Park MK, Qureshi AA, Cho E: The role of micronutrients in alopecia areata: A review. Am J Clin Dermatol. 2017, 18:663-679. 10.1007/s40257-017-0285-x

8. Aksu Cerman A, Sarikaya Solak S, Kivanc Altunay I: Vitamin D deficiency in alopecia areata . Br J Dermatol 2014, 170:1299-1304. 10.1111/bjd.12980

9. Lee S, Kim BJ, Lee CH, Lee WS: Increased prevalence of vitamin D deficiency in patients with alopecia areata: a systematic review and meta-analysis. J Eur Acad Dermatol Venereol. 2018, 32:1214-1221. 10.1111/jdv.14987

10. Unal M, Gonulalan G: Serum vitamin D level is related to disease severity in pediatric alopecia areata . J Cosmet Dermatol. 2018, 17:101-104. 10.1111/jocd.12352

11. Gade VKV, Mony A, Munisamy M, Chandrashekar L, Rajappa M: An investigation of vitamin D status in alopecia areata. Clin Exp Med. 2018, 18:577-584. 10.1007/s10238-018-0511-8

12. Akar A, Orkunoglu FE, Tunca M, Taştan HB, Kurumlu Z: Vitamin D receptor gene polymorphisms are not associated with alopecia areata. Int J Dermatol. 2007, 46:927-929. 10.1111/j.1365-4632.2007.03140.x

13. Fawzi MMT, Mahmoud SB, Ahmed SF, Shaker OG: Assessment of vitamin D receptors in alopecia areata and androgenetic alopecia. J Cosmet Dermatol. 2016, 15:318-323. 10.1111/jocd.12224

14. Daroach M, Narang T, Saikia UN, Sachdeva N, Sendhil Kumaran M: Correlation of vitamin D and vitamin D receptor expression in patients with alopecia areata: a clinical paradigm. Int J Dermatol. 2018, 57:217-222. 10.1111/ijd.13851

15. Abdel Fattah NSA, Atef MM, Al-Qaradaghi SMQ: Evaluation of serum zinc level in patients with newly diagnosed and resistant alopecia areata. Int J Dermatol. 2016, 55:24-29. 10.1111/ijd.12769

16. Lee SY, Nam KS, Seo YW, Lee JS, Chung H: Analysis of serum zinc and copper levels in alopecia areata. Ann Dermatol. 1997, 9:239-241. doi.org/10.1016/j.jaad.2003.10.292

17. Orecchia G, Perfetti L, Minoia C, Rabbiosi G: Determination of plasma zinc values in patients with alopecia areata. Ann Ital Dermatol Sifilogr. 1990, 44:17-23.

18. Ehsani AH, Hosseyni MS, Hanifnia AR: Serum zinc level in alopecia areata patients: a cross-sectional study . Dermatol Cosmet. 2012, 3:40-44.

19. García-Hernández M, Muñoz M, Rodríguez-Pichardo A, Camacho F: Zinc aspartate, biotin and clobetasol propionate in the treatment of alopecia areata in childhood. J Eur Acad Dermatol Venereol. 1997, 16(4):3368.. doi.org/10.1111/j.1525-1470.1999.pdele65.x 